\title{
Faktor-faktor yang mempengaruhi impor beras di Indonesia Tahun 2001-2019
}

\author{
Dian Mashitoh Azzahra*; Amri Amir; Siti Hodijah \\ Prodi Ekonomi Pembangunan Fak.Ekonomi dan Bisnis, Universitas Jambi \\ *E-mail korespondensi: prantiko157@gmail.com
}

\begin{abstract}
The objectives of this study are as follows: (1) To determine and analyze the development of rice imports, rice production, population, and rice consumption in Indonesia in 2001 2019. (2) To determine and analyze the effect of rice production, population, and rice consumption on rice imports in Indonesia in 2001-2019. Based on the research results, (1) Rice imports in Indonesia fluctuate every year, and the development of the population in Indonesia has increased. The effect of rice consumption in Indonesia fluctuates from year to year. The story of rice production in Indonesia also fluctuates. (2) The regression results show that the population has a positive and significant effect on rice imports in Indonesia. Rice consumption has a positive and significant effect on rice imports in Indonesia. Rice production does not affect rice imports in Indonesia.
\end{abstract}

Keywords: Population, Rice consumption, Rice production

\begin{abstract}
Abstrak
Adapun yang menjadi tujuan penelitian ini adalah sebagai berikut : (1) Untuk mengetahui dan menganalisis perkembngan impor beras, produksi beras, jumlah penduduk dan konsumsi beras di Indonesia Tahun 2001-2019. (2) Untuk mengetahui dan menganalisis pengaruh produksi beras, jumlah penduduk dan konsumsi beras terhadap impot beras di Indonesia tahun 2001-2019. Berdasarkan hasil penelitian bahwa (1) Impor beras di Indonesia perkembangan mengalami fluktuasi tiap tahunya, begitu pula dengan perkembangan jumlah penduduk di Indonesia mengalami peningkatan. Perkembangan konsumsi beras di Indonesia mengalami fluktuasi dari tahun ketahun. Perkembangan produksi beras di Indonesia juga mengalami fluktuasi. (2) Hasil regresi menunjukan jumlah penduduk berpengaruh positif dan signifikan terhadap impor beras di Indonesia, konsumsi beras berpengaruh positif dan signfikan terhadap impor beras di Indonesia. Produksi beras tidak berpengaruh terhadap impor beras di Indonesia.
\end{abstract}

Kata kunci:Jumlah penduduk, Konsumsi Beras, Produksi Beras

\section{PENDAHULUAN}

Perdagangan merupakan suatu hal yang sangat penting dalam kegiatan perekonomian suatu negara. Giatnya aktivitas perdagangan suatu negara menjadi indikasi tingkat kemakmuran masyarakatnya,serta menjadi tolak ukur tingkat perekonomian negara itu sendiri. Sehingga bisa dibilang perdagangan merupakan urat nadi perekonomian suatu negara. Melalui perdagangan pula suatu negara bisa menjalin hubungan diplomatik dengan negara tetangga sehingga secara tidak langsung 
perdagangan juga berhubungan erat dengan dunia politik. Perdagangan atau perniagaan pada umumnya adalah pekerjaan membeli barang dari suatu tempat dan suatu waktu dan menjual barang tersebut di tempat dan waktu lainnya untuk memperoleh keuntungan. Kegiatan impor yang dilakukan indonesia merupakan salah satu kebijakan pemerintah dalam bidang perdagangan internasional. Terjadinya selisih antara jumlah produksi dengan jumlah kebutuhan masyarakat merupakan salah satu penyebab diterapkannya kebijakan impor (Tambunan,2012)

Impor adalah arus masuk sejumlah barang dan jasa ke pasar suatu negara,baik untuk keperluan konsumsi atau sebagai barang modal maupun untuk bahan baku produksi dalam negri. Negara importir biasanya melakukan kegiatan impor dengan tujuan memenuhi kebutuhan masyarakat dalam negri,menambah pendapatan negara karna adanya devisa dari pajak barang impor. Selain itu impor juga dimaksudkan untuk mendorong berkembangnya kegiatan industri dalam negri. Kegiatan impor inilah yang nantinya membentuk dasar dari perdagangan internasional Armaini, Desi \& Gunawan, Eddy (2016).

Dalam konteks pertanian umum, Indonesia memang memiliki potensi yang besar,kelapa sawit,karet dan coklat produksi indonesia mulai bergerak menguasai pasar dunia. Namun,meski menduduki posisi ketiga sebagai negara penghasil pangan di dunia,hampir setiap tahun Indonesia selalu menghadapi persoalan berulang dengan produksi pangan terutama beras. Akibatnya Indonesia masih harus mengimpor beras dari Negara penghasil pangan lain seperti Thailand.

Produksi padi Indonesia mengambil pangsa sekitar 9\% dari total produksi dunia. Indonesia negara penghasil beras ke tiga terbesar di dunia,setelah China(30\%) dan India(21\%). Namun,ke dua negara terakhir adalah net eksportir beras ,berbeda dengan indonesia yang menjadi negara net importir beras sejak 1980 an. Indonesia terus berusaha mendorong peningkatan produksi beras dalam negeri dan mengelola stok beras nasional untuk tujuan emerjensi dan stabilisasi harga. Produksi beras/padi dalam negri amat penting untuk menghindari tinggi nya resiko ketidakstabilan harga dan suplai beras dari pasar dunia,di samping terkait erat dengan usaha pengentasan kemiskinan dan pembangunan pedesaan (Muhtadi,2007).

Negara indonesia merupakan negara yang mempunyai kekayaan sumber daya alam yang melimpah. Hal ini terbukti dengan keadaan tanah Indonesia yang sangat subur. Negara Indonesia memiliki peran penting sebagai produsen bahan pangan di mata dunia. Kontribusi Indonesia terhadap produksi beras dunia 8,5\% atau 51 juta ton. China dan India sebagai produsen utama beras berkontribusi 54\%. Vietnam dan Thailand yang secara tradisional merupakan negara eksportir beras hanya berkontribusi 5,4\% dan 3,9\%. Produksi beras indonesia yang begitu tinggi belum bisa mencukupi kebutuhan penduduk nya. Akibatnya indonesia masih harus mengimpor beras dari Negara penghasil pangan lain seperti Thailand.

Beras merupakan komoditi yang sangat utama karena dikonsumsi oleh sebagian besar penduduk Indonesia. Selain sebagai sumber karbohidrat, dua pertiga kebutuhan kalori diperoleh dari beras. Beras sebagai salah satu pangan yang sangat dibutuhkan dan dijadikan sebagai salah satu makanan pokok di Indonesia. Tidak dapat dipungkiri lagi bahwa sejak dulu dan hingga nanti pun manusia memerlukan makanan untuk bertahan hidup. Pangan telah menjadi kebutuhan primer manusia yang harus dipenuhi sebelum memenuhi kebutuhan hidup lainnya seperti sandang, papan dan pendidikan. 
Komoditi pangan yang sangat penting bagi bangsa Indonesia adalah beras, terutama karena: (1) beras merupakan bahan pangan dan sumber kalori yang utama bagi sebagian besar bangsa Indonesia, yakni lebih dari 90 persen dari total penduduk di Indonesia; (2) usahatani padi menyediakan lapangan kerja bagi 21 juta keluarga petani dan: (3) sekitar 30 persen dari total pengeluaran rumah tangga miskin dipergunakan untuk membeli beras. Selain itu, pangsa beras dalam konsumsi kalori total adalah 54,3 persen dan berkontribusi sebesar 40 persen dalam asupan protein.

Indonesia terus berusaha mendorong peningkatan produksi beras dalam negeri dan mengelola stok beras nasional untuk tujuan emerjensi dan stabilisasi harga. Produksi beras dalam negeri amat penting untuk menghindari tingginya risiko ketidakstabilan harga dan suplai beras dari pasar dunia, disamping terkait erat dengan usaha pengentasan kemiskinan dan pembangunan perdesaan. Maka menjadi tugas pemerintah dalam menetapkan kebijakan yang akan menjamin ketahanan pangan dan kebijakan swasembada beras di Indonesia. Hal ini mengakibatkan produk-produk dalam negeri tidak dapat bersaing dengan produk impor, akibatnya volume impor akan lebih kecil mengalami penurunan tiap tahunnya. Perkembangan produksi dan impor beras di Indonesia tahun 2015-2019 dapat dilihat pada tabel 1.1

Tabel 1. Impor, jumlah penduduk, konsumsi dan produksi beras di Indonesia Periode Tahun 2015-2019

\begin{tabular}{ccccc}
\hline Tahun & $\begin{array}{c}\text { Impor beras } \\
\text { (Ton) }\end{array}$ & $\begin{array}{c}\text { Jumlah penduduk } \\
\text { (Juta) }\end{array}$ & $\begin{array}{c}\text { Konsumsi beras } \\
\text { (Ton) }\end{array}$ & $\begin{array}{c}\text { Produksi } \\
\text { (Ton) }\end{array}$ \\
\hline 2015 & 861.601 & 258.4 & 33.144 .541 & 47.304 .605 \\
2016 & 1.283 .178 & 261.6 & 33.470 .000 & 79.140 .000 \\
2017 & 305.274 & 264.6 & 29.130 .000 & 81.380 .000 \\
2018 & 2.253 .824 & 265.0 & 26.300 .000 & 33.940 .000 \\
2019 & 444.508 & 267.0 & 31.310 .000 & 31.310 .000 \\
\hline
\end{tabular}

Sumber: Badan Pusat Statistik, 2020(diolah)

Berdasarkan Tabel 1. dapat dilihat bahwa impor beras di indonesia dari tahun 20152019 mengalami fluktuasi. Pada Tahun 2015 impor beras di Indonesia sebanyak 861.601 ton. Pada Tahun 2016 impor mengalami peningkatan menjadi sebanyak 1.283.278 ton. Pada Tahun 2017 mengalami penurunan menjadi sebanyak 305.274 ton. Pada Tahun 2018 meningkat impor menjadi sebanyak 2.253.824 ton. Pada tahun 2019 impor beras di Indonesia mengalami penurunaun menjadi sebanyak 444.508 ton.

Salah satu penyebab terjadinya kekurangan stok beras dikarenakan produksi dalam daerah semakin berkurang ini di sebabkan oleh kekurangan luas lahan padi sawah akibat terjadinya alih fungsi lahan pertanian untuk membangun perumahan,perkantoran maupun perusahaan-perusahaan besar. Disamping itu terjadinya ledakan jumlah penduduk juga merupakan suatu masalah yang di hadapi oleh pemerintah.

Pertambahan penduduk merupakan suatu tantangan bagi pemerintah terutama dalam menjaga ketahanan pangan bagi masyarakat. Pertumbuhan penduduk menyebabkan terjadinya permintaan terhadap barang-barang konsumsi terutama barang bahan pokok seperti beras oleh karna itu pemerintah harus berupaya semaksimal mungkin dalam memenuhi kebutuhan beras masyarakat terutama melalui perluasan area lahan sawah baru dalam upaya meningkatkan produksi. Jumlah penduduk mempengaruhi impor 
karna apabila jumlah penduduk meningkat maka kemungkinan pemerintah akan mengambil kebijakan untuk mengimpor Dwipayana, I Kadek Agus dkk. (2014). Dari segi penawaran,impor di pengaruhi variabel produksi,dimana secara logika kecenderungan permintaan beras yang lebih besar di bandingkan produksi beras menyebabkan terjadinya defisit produksi.

Berdasarkan dari Badan Pusat Statistik Jumlah Penduduk mengalami peningkatan dari tahun 2015-2019. Pada tahun 2015 jumlah penduduk sebanyak 257.4 juta jiwa. pada tahun 2016 mengalami peningkatan menjadi sebanyak 261.6 juta jiwa. Pada tahun 2017 mengalami peningkatan kembali menjadi sebanyak 264.6 juta jiwa. Pada tahun 2018 kembali mengalami peningkatan menjadi sebanyak 265.0 juta jiwa. Pada tahun 2019 jumlah penduduk mengalami peningkatan dari tahun-tahun sebelumhya menjadi sebanyak 267.0 juta jiwa

Berdasarkan dari Tabel 1. konsumsi beras mengalami fluktuas dari Tahun 20152019. Pada Tahun 2015 konsumsi beras sebanyak 33.144.541 ton. Pada Tahun 2016 mengalami peningkatan menjadi sebanyak 33.470.000 ton. Pada Tahun 2017 mengalami penurunan menjadi sebanyak 29.130.000 ton. Pada Tahun 2018 kembali mengalami penurunan menjadi sebanyak 26.300.000 ton. Pada Tahun 2019 konsumsi beras mengalami peningkatan dari tahun-tahun sebelumhya menjadi sebanyak 31.310.000 ton

Berdasarkan dari data yang didapat terlihat bahwa produksi beras mengalami fluktuasi dari Tahun 2015-2019. Pada Tahun 2015 konsumsi beras sebanyak 47304605 ton. Pada Tahun 2016 mengalami peningkatan menjadi sebanyak 79.140.000 ton. Pada Tahun 2017 mengalami peningkatan menjadi sebanyak 81.380.000 ton. Pada Tahun 2018 mengalami penurunan menjadi sebanyak 33.940.000 ton. Pada tahun 2019 konsumsi beras mengalami penurunan dari tahun-tahun sebelumhya menjadi sebanyak 31.310 .000 ton. Berdasarkan latar belakang yang telah diuraikan diatas penulis tertarik melakukan penelitian lebih lanjut dengan judul "Faktor faktor mempengaruhi impor beras di indonesia pada Tahun 2001-2019"

\section{METODE}

Data yang digunakan adalah data kuantitatif dalam bentuk runtun waktu (time series) dari periode tahun 2001-2019. Metode analisis data dalam penelitian ini adalah metode deskriptif dan kuantitatif.

\section{Metode deskriptif}

Untuk menjawab permasalahan dan tujuan penelitian pertama digunakan rumus berikut:

Keterangan:

$$
G=\frac{I B_{t}-I B_{t-1}}{I B_{t-1}} X 100 \%
$$

$\mathrm{G}=$ Perkembangan impor beras Indonesia

$\mathrm{IB}_{\mathrm{t}}=$ Impor beras tahun tertentu (tahun $\mathrm{t}$ )

$\mathrm{IB}_{\mathrm{t}-1}=$ Impor beras tahun sebelumnya (tahun $\mathrm{t}-1$ )

\section{Metode kuantitatif}

Untuk menjawab tujuan kedua penelitian ini, yaitu pengaruh produksi beras, jumlah penduduk dan konsumsi beras terhadap impot beras di Indonesia tahun 2001-2019 penulis menggunakan model regresi berganda dengan persamaan sebagai berikut : 


\section{$\operatorname{LogIB}=\beta_{0}+\beta_{1} \operatorname{logJP}+\beta_{2} \log \mathrm{KB}+\beta_{3} \log \mathrm{PB}+\mathrm{e}$}

Dimana :

IB $\quad=$ Impor beras Indonesia

$\mathrm{JP} \quad=$ Jumlah penduduk

$\mathrm{KB} \quad=$ Konsumsi beras

$\mathrm{PB} \quad=$ Produksi beras

$\mathrm{B}_{0} \quad=$ Konstanta

$\mathrm{B}_{1}, \mathrm{~B}_{2}, \mathrm{~B}_{3}=$ Koefisien regresi

$\mathrm{e}=$ Variabel gangguan

\section{HASIL DAN PEMBAHASAN}

\section{Perkembangan impor beras}

Menurut Tan (2016) Impor adalah proses memasukan barang dari luar negeri kedalam pabean dalam negeri dengan memenuhi ketentuan peraturan perundangundangan yang berlaku. Perdagangan impor dilakukan untuk mendatangkan brang dari luar negeri dan dipasarkan didalam negeri. Pada prisipnya pendatangan barang dari luar negeri akan mengurangi cadangan devisa, tetapi bagaimanapun juga perdagangan impor memang perlu dilakukan karena pengadaan barang tersebut dilakukan pada dasarnya belum dapat dipenuhi kebutuhan oleh produksi di dalam negeri. Beras merupakan komoditi strategis sebagai bahan pangan bagi masyarakat Indonesia, sehingga kegiatan produksi, penyediaan, pengadaan dan distribusi beras menjadi sangat penting dalam rangka ketahanan pangan, peningkatan pendapatan dan kesejahteraan petani, dalam rangka stabilitas kepentingan konsumsi masyarakat secara umum. Perkembangan produksi beras di Indonesia sejak tahun 2001-2019 terlihat meningkat di setiap tahunya hal ini dapat dilihat pada Tabel 2 berikut.

Tabel 2. Impor beras di Indonesia Tahun 2001-2019

\begin{tabular}{lcc}
\hline Tahun & Impor Beras (Ton) & Perkembangan (\%) \\
\hline 2001 & 644.733 & - \\
2002 & 1.805 .380 & 180.02 \\
2003 & 1.428 .506 & -20.87 \\
2004 & 236.867 & -83.41 \\
2005 & 189.617 & -19.94 \\
2006 & 438.109 & 131.04 \\
2007 & 1.406 .848 & 221.11 \\
2008 & 289.689 & -79.40 \\
2009 & 250.473 & -13.53 \\
2010 & 687.582 & 174.51 \\
2011 & 2.750 .476 & 300.02 \\
2012 & 1.810 .372 & -34.18 \\
2013 & 472.665 & -73.89 \\
2014 & 844.164 & 78.59 \\
2015 & 861.601 & 2.06 \\
2016 & 1.283 .178 & 48.92 \\
2017 & 305.274 & -76.21 \\
2018 & 2.253 .824 & 638.29 \\
2019 & 444.508 & -80.27 \\
\hline
\end{tabular}

Sumber : Badan Pusat Statistik 2020(diolah) 
Berdasarkan dari Tabel 2 menunjukkan bahwa perkembangan impor beras di Indonesia dari tahuun 2001-2019 mengalami flutuasi. Perkembangan imporberas yang paling tertinggi terjadi pada tahun 2018 yaitu sebesar 638,29 persen atau daru 305.274 ton meningkat menjadi 2.253 .824 ton. Sedangkan perkembangan impor beras yang rendah terjadi pada tahun 2004 yaitu sebesar -83.41 atau dari 1.805 .380 ton menurun menjadi 1.428 .506 ton. Rata-rata perkembangan impor beras di Indonesia dari tahun 2001-2019 adalah sebesar 68.04 persen pertahun.

\section{Perkembangan penduduk}

Penduduk adalah orang yang secara hukum berhak tinggal di dalam suatu daerah. Dengan kata lain orang yang mempunyai surat resmi untuk tinggal di daerah tersebut. Untuk melihat lebih jelas perkembangan jumlah penduduk di Indonesia sejak tahun 20012019 dapat diihat pada Tabel 3.

Jumlah penduduk Indonesia mengalami peningkatan dari tahun ketahun dengan pertumbuhan tertinggi terjadi pada tahun 2002 sebesar 6,04 atau sebanyak 217,4 juta Jiwa, hal ini disebabkan oleh terjadinya ledakan angka kelahiran (Fertilitas) dan pertumbuhan terendah terjadi pada tahun 2018 sebesar $0,15 \%$ atau sebanyak 265,0 juta jiwa yang disebabkan oleh rendahnya angka kelahiran.

Tabel 3. Perkembangan jumlah penduduk Indonesia Tahun 2001-2019

\begin{tabular}{ccc}
\hline Tahun & $\begin{array}{c}\text { Jumlah Penduduk } \\
\text { (Juta jiwa) }\end{array}$ & $\begin{array}{c}\text { Perkembangan } \\
(\boldsymbol{\%})\end{array}$ \\
\hline 2001 & 205.0 & - \\
2002 & 217.4 & 6.04 \\
2003 & 220.3 & 1.33 \\
2004 & 223.3 & 1.36 \\
2005 & 226.3 & 1.34 \\
2006 & 229.3 & 1.32 \\
2007 & 232.4 & 1.35 \\
2008 & 235.5 & 1.33 \\
2009 & 238.6 & 1.31 \\
2010 & 241.8 & 1.34 \\
2011 & 245.1 & 1.36 \\
2012 & 248.5 & 1.38 \\
2013 & 251.8 & 1.32 \\
2014 & 255.1 & 1.31 \\
2015 & 258.4 & 1.29 \\
2016 & 261.6 & 1.23 \\
2017 & 264.6 & 1.14 \\
2018 & 265.0 & 0.15 \\
2019 & 267.0 & 0.75 \\
\hline
\end{tabular}

Sumber : Badan Pusat Statistik, 2020(diolah) 


\section{Perkembangan konsumsi beras}

Mankiw (2007), mendefiniskan konsumsi sebagaipembelanjaan barang dan jasa oleh rumah tangga. Konsumsi merupakan fungsi dari pendapatan siap pakai atau disposabel income yang menunjukkan hubungan antara tingkat pengeluaran konsumsi dengan tingkat pendapatan yang siap di belanjakan. Tingginya pertumbuhan penduduk yang diikuti besarnya konsumsi beras membuat permintaan beras semakin naik sehingga hal tersebut masih belum bisa diwujudkan karena kenaikan jumlah produksi beras dimaksudkan untuk mengimbangi peningkatan jumlah penduduk yang mengkonsumsi beras. Untuk melihat perkembangan konsumsi beras di Indonesia Tahun 2001-2019 dapat dilihat pada Tabel 4.

Berdasarkan dari Tabel 4 terlihat bahwa perkembangan konsumsi beras di Indonesia dari tahuun 2001-2019 mengalami flutuasi. Rata-rata Perkembangan konsumsi dari tahun 2001-2019 yaitu sebesar 2,34 persen pertahun. perkembangan konsumsi beras yang paling tertinggi terjadi pada tahun 2009 yaitu sebesar 17,66 persen atau dari 27.865.795 ton meningkat menjadi 32.788.170 ton hal ini terjadi karena dengan konsumsi beras meningkat dipengaruhi oleh peningkatan dari jumlah penduduk dengan meningkatnya jumlah penduduk maka konsumsi beras pun juga akan meningkat. Sedangkan perkembangan konsumsi beras yang rendah terjadi pada tahun 2017 yaitu sebesar -12,96 persen atau dari 33.470.000 ton menurun menjadi 29.130.000 ton.

Tabel 4. Konsumsi Beras di Indonesia 2001- 2019

\begin{tabular}{|c|c|c|}
\hline Tahun & $\begin{array}{c}\text { Konsumsi Beras } \\
\text { (Ton) }\end{array}$ & $\begin{array}{c}\text { Perkembangan } \\
(\%)\end{array}$ \\
\hline 2001 & 21673175 & - \\
\hline 2002 & 22655989 & 4.53 \\
\hline 2003 & 22993563 & 1.49 \\
\hline 2004 & 23336167 & 1.50 \\
\hline 2005 & 24394392 & 4.54 \\
\hline 2006 & 25500605 & 4.52 \\
\hline 2007 & 26656981 & 4.54 \\
\hline 2008 & 27865795 & 4.53 \\
\hline 2009 & 32788170 & 17.66 \\
\hline 2010 & 33189891 & 1.22 \\
\hline 2011 & 33673006 & 1.45 \\
\hline 2012 & 34150917 & 1.41 \\
\hline 2013 & 34623039 & 1.38 \\
\hline 2014 & 31268435 & -9.68 \\
\hline 2015 & 33144541 & 6.00 \\
\hline 2016 & 33470000 & 0.98 \\
\hline 2017 & 29130000 & -12.96 \\
\hline 2018 & 26300000 & -9.71 \\
\hline 2019 & 31310000 & 19.04 \\
\hline
\end{tabular}

Sumber: Badan Pusat Statistik 2020(diolah) 


\section{Perkembangan produksi beras}

Menurut Noor (2010) produksi merupakan suatu kegiatan yang mengolah input baik berupa barang dan jasa menjadi output berupa barang dan jasa yang lebih bernilai atau bermanfaat bagi konsumen, untuk menghasilkan produk dengan kriteria tersebut, diperlukan beberapa tahap dan faktor produksi yang satu dengan lainya harus seimbang. Peningkatan produksi beras di dalam negeri selain memberi manfaat pada penghematan devisa nasional, juga dapat membuka kesempatan kerja dan mengurangi kemiskinan. Jumlah produksi beras adalah penentu seberapa besar tingkat kinerja petani dalam mengolah lahan pertanian. Beras merupakan bahan makanan pokok masyarakat Indonesia. Oleh sebab itu, tingkat konsumsi beras yang sangat besar di Indonesia harus diiringi dengan tingkat produksi beras yang sepadan, agar Indonesia tidak bergantung pada sektor impor untuk mencukupi kebutuhan pokoknya. Selain itu, peningkatan produksi beras juga diharapkan untuk meningkatkan kesejahteraan masyarakat terutama petani Indonesia. Untuk melihat perkembangan produksi beras di Indonesia dari tahun 2001-2019 dapat dilihat pada Tabel 5.

Berdasarkan dari Tabel 5 menunjukkan bahwa perkembangan produksi beras di Indonesia dari tahuun 2001-2019 mengalami fluktuasi. Perkembangan produksi beras yang paling tertinggi terjadi pada tahun 2009 yaitu sebesar 5.97 persen atau dari 38.125.985 ton meningkat menjadi 40.403 .846 ton. Sedangkan perkembangan impor beras yang rendah terjadi pada tahun 2018 yaitu sebesar $-58,29$ persen atau dari 81.380.000 ton pada tahun 2017 menurun menjadi 33.940.000 ton pada tahun 2018. Ratarata perkembangan produksi beras di Indonesia dari tahun 2001-2019 adalah sebesar 2,34 persen pertahun.

Tabel 5. Produksi beras di Indonesia tahun 2001-2019

\begin{tabular}{ccc}
\hline Tahun & $\begin{array}{c}\text { Produksi beras } \\
\text { (Ton) }\end{array}$ & $\begin{array}{c}\text { Perkembangan } \\
(\boldsymbol{\%})\end{array}$ \\
\hline 2001 & 31891214 & - \\
2002 & 32541487 & 2.03 \\
2003 & 32950966 & 1.25 \\
2004 & 34183912 & 3.74 \\
2005 & 34223493 & 0.11 \\
2006 & 34415520 & 0.56 \\
2007 & 36123499 & 4.96 \\
2008 & 38125985 & 5.54 \\
2009 & 40403846 & 5.97 \\
2010 & 41702898 & 3.21 \\
2011 & 41255882 & -1.07 \\
2012 & 43325813 & 5.01 \\
2013 & 44720889 & 3.21 \\
2014 & 43873034 & -1.89 \\
2015 & 47304605 & 7.82 \\
2016 & 79140000 & 67.29 \\
2017 & 81380000 & 2.83 \\
2018 & 33940000 & -58.29 \\
2019 & 31310000 & -7.74 \\
\hline
\end{tabular}

Sumber: Badan Pusat Statistik, 2020(diolah) 


\section{Analisis regresi linear berganda}

Pada bagian ini akan dipresentasikan pengaruh jumlah penduduk, konsumsi beras dan produksi beras terhadap impor beras. Sebagai variabel independen (bebas) adalah jumlah penduduk, konsumsi beras dan produksi beras, sedangkan variabel dependent adalah impor beras. Dari hasil regresi linear berganda diperoleh hasil estimasi sebagai berikut:

Tabel 6. Hasil regresi berganda

\begin{tabular}{|c|c|c|c|c|c|c|}
\hline & \multirow[t]{2}{*}{ Model } & \multicolumn{2}{|c|}{$\begin{array}{l}\text { Unstandardized } \\
\text { Coefficients }\end{array}$} & \multirow{2}{*}{$\begin{array}{c}\begin{array}{c}\text { Standardized } \\
\text { Coefficients }\end{array} \\
\text { Beta } \\
\end{array}$} & \multirow[t]{2}{*}{$\mathbf{T}$} & \multirow[t]{2}{*}{ Sig. } \\
\hline & & B & Std. Error & & & \\
\hline \multirow[t]{6}{*}{1} & (Constant) & - & 20,519 & & $-8,056$ & 000 \\
\hline & & 165,29 & & & & \\
\hline & & 6 & & & & \\
\hline & Jumlah Penduduk & 26,412 & 9,284 & ,458 & 2,845 & ,012 \\
\hline & Konsumsi & 15,294 & 4,275 &, 560 & 3,578 & ,003 \\
\hline & Produksi &,- 931 & 2,012 &,- 057 &,- 463 & 650 \\
\hline
\end{tabular}

a. Dependent Variable: impor beras

Sumber: Data diolah, 2020

Dari hasil pengolahan data dengan menggunakan SPSS 20 maka didapat hasil persamaan regresi sebagai berikut ini :

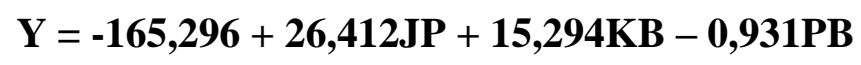

Hasil regresi linear berganda diketahui bahwa hasil pengolahan data adalah sebagai berikut : Nilai konstanta (a) sebesar-165,296 hal ini berarti bahwa jika jumlah penduduk, konsumsi beras dan produksi beras, adalah konstan atau nol atau tidak berubah maka impor beras di Indonesia sebesar -165,296. Koefesien jumlah penduduk sebesar 26,412, hal ini berarti setiap peningkatan jumlah penduduk sebesar 1 persen maka akan meningkatkan impor beras Indonesia sebesar 26,412 persen dengan asumsi konsumsi beras, produksi beras dan impor beras Indonesia dalam keadaaan relatif atau tidak berubah. Koefesien Konsumsi beras sebesar 15,294, hal ini berarti setiap peningkatan konsumsi beras sebesar 1 persen maka akan meningkatkan impor beras Indonesia sebesar 15,294 persen dengan asumsi jumlah penduduk, produksi beras, dan impor beras Indonesia dalam keadaaan relatif atau tidak berubah. Koefesien produksi beras sebesar $-0,931$ hal ini berarti setiap peningkatan produksi beras sebesar 1 persen maka akan menurunkan impor beras Indonesia sebesar 0,931 persen dengan asumsi jumlah penduduk, konsumsi beras, dan impor beras Indonesia dalam keadaan relatif tetap atau tidak berubah

\section{Uji hipotesis}

Setelah memilih model mana yang terbaik dilanjutkan dengan uji hipotesis. Uji hipotesis dilakukan dengan uji signifikan statistik secara uji F dan parsial atau uji-t.

\section{Uji simultan (Uji F)}

Hasil regresi menunjukan nilah $\mathrm{F}$ hitung sebesar 28,943 dengan tingkat kepercayaan 95\%, diperoleh nilai $\mathrm{F}$ tabel sebesar 3,13 hasil regresi menunjukan Fhitung 
$>\mathrm{F}$ tabel maka (Ho) ditolak dan (Ha) diterima artinya secara bersama-sama jumlah penduduk, konsumsi beras dan produksi beras, berpengaruh signifikan terhadap impor beras di Indonesia

\section{Uji parsial (Uji t)}

Untuk mengetahui variabel bebas pengaruhya terhadap variabel terikat, uji $\mathrm{t}$ dilakukan dengan membandingkan nilai uji t hitung dengan $t$ tabel (Ghozali, 2011). Hasil regresi menunjukan nilai t hitung untuk variabel jumlah penduduk adalah sebesar 2,84 dengan tingkat kepercayaan $95 \%$ diperoleh $t$ tabel sebesar 1,729 hasil regresi menunjukan $\mathrm{t}$ hitung $>\mathrm{t}$ tabel maka dalam hal ini (Ho) ditolak dan (Ha) diterima yang artinya jumlah penduduk memiliki pengaruh positif dan signifikan terhadap impor beras di Indonesia . Hasil regresi menunjukan nilai t hitung untuk variabel konsumsi beras adalah sebesar 3,578 dengan tingkat kepercayaan 95\% diperoleh t tabel sebesar 1,729 hasil regresi menunjukan $\mathrm{t}$ hitung $>\mathrm{t}$ tabel maka dalam hal ini (Ho) ditolak dan (Ha) diterima yang artinya konsumsi beras memiliki pengaruh positif dan signifikan terhadap impor beras di Indonesia. Hasil regresi menunjukan nilai t hitung untuk variabel produksi beras adalah sebesar -0,463 dengan tingkat kepercayaan 95\% diperoleh t tabel sebesar 1,729 hasil regresi menunjukan thitung < t tabel maka dalam hal ini (Ho) diterima dan (Ha) ditolak yang artinya produksi beras tidak memiliki pengaruh signifikan terhadap impor beras di Indonesia

\section{Koefisien determinasi}

Nilai $\mathrm{R}^{\mathbf{2}}$ menunjukan seberapa besar proporsi variabel bebas berpengaruh terhadap variabel terikat (Gujarati, 2003). Hasil regresi dapat dilihat dari nilai $\mathrm{R}^{2}$ sebesar 0,853 artinya 85,3 persen impor beras di Indonesia dipengaruhi oleh jumlah penduduk, konsumsi beras dan produksi beras sedangkan sisanya sebesar 14,7 persen diperngaruhi oleh variabel lain yang tidak termasuk dalam penelitian ini.

\section{Implikasi kebijakan}

Berdasarakan dari hasil terlihat produksi beras tidak berpengaruh terhadap impor beras diharapkan pemerintah dapat memperhatikan impor beras di Indonesia sesuai dengan kebutuhan dalam negeri sehingga pengeluaran yang terjadi terhadap pendapatan nasional dapat ditekan, serta pemerintah dapat meningkatan produksi beras dalam negeri melalui pemberdayaan sektor pertanian yang lebih baik lagi. Pemerintah sebaiknya mampu menjaga kestabilan ekonomi dalam negeri dan meningkatkan kegiatan produksi dalam negeri sehingga dapat mengurangi ketergantungan impor beras dari luar negeri.

Pemerintah harus selalu dapat meningkatan perhatian dalam kebijakan dalam produksi beras yang ada di Indonesia. Diharapkan perlu adanya upaya lebih keras lagi agar produksi beras dapat menigkat melebihi dari kebutuhan nasional namun juga kesejahteraan perani sehingga SDM yang bekerja di bidang pertanian tidak alih profesi dan lalu menjual lahan miliknya. Diharapkan juga memperhatikan keadaan sarana dan prasarana pertanian dan hal-hal yang berkaita dengan irigasi, pupuk bibit, distribusi dan lainya. Gunanya agar mencapai kelancaran dalam peningkatan beras yang ada di Indonesia, dengan adanya kebijakan ini diharapkan nantinya dapat mengurangi ketergantungan dalam impor beras. 


\section{KESIMPULAN DAN SARAN}

\section{Kesimpulan}

Impor beras di Indonesia perkembangan mengalami fluktuasi tiap tahunya, begitu pula dengan perkembangan jumlah penduduk di Indonesia mengalami peningkatan. Perkembangan konsumsi beras di Indonesia mengalami fluktuasi dari tahun ketahun. Perkembangan produksi beras di Indonesia juga mengalami fluktuasi

Hasil regresi menunjukan jumlah penduduk berpengaruh positif dan signifikan terhadap impor beras di Indonesia, konsumsi beras berpengaruh positif dan signfikan terhadap impor beras di Indonesia. Produksi beras tidak berpengaruh terhadap impor beras di Indonesia.

\section{Saran}

Variabel produksi beras tidak berpengaruh terhadap impor beras berdasarkan hasil tersebut diharapkan pemerintah pemerintah dapat meningkatan produksi beras dalam negeri melalui pemberdayaan sektor pertanian yang lebih baik lagi. Pemerintah sebaiknya mampu menjaga kestabilan ekonomi dalam negeri dan meningkatkan kegiatan produksi dalam negeri sehingga dapat mengurangi ketergantungan impor beras dari luar negeri.

Hasil regresi juga menunjukan bahwa konsumsi berpengaruh terhadap impor beras. Dari sisi konsumsi, upaya yang dapat dilakukan ialah dengan memperbaiki pola pangan harapan di Indonesia menjadi pola pangan harapan yang ideal dengan komposisi pangan yang seimbang, sehingga konsumsi beras dapat ditekan.

\section{DAFTAR PUSTAKA}

Armaini, Desi \& Gunawan, Eddy. (2016), Pengaruh produksi beras, harga beras dalam negeri, dan produk domestik bruto terhadap impor Beras Indonesia, Jurnal Ilmiah Mahasiswa (JIM) Ekonomi Pembangunan Fakultas Ekonomi dan Bisnis Unsyiah, 1(2), 455-466.

Badan Pusat Statistik (BPS). Statistik Indonesia 2001-2019: Statistical yearbook of Indonesia. BPS.Jakarta,

C Mustika, A Amril. (2015).Analisis pengaruh ekspor ke jepang terhadap pertumbuhan ekonomi dan jumlah pengangguran di Indonesia Periode 1993 sampai 2013, Jurnal Paradigma Ekonomika, 10 (1).

Dwipayana, I Kadek Agus dkk. (2014). Pengaruh harga,cadangan devisa, dan jumlah penduduk terhadap impor beras Indonesia. E-Jurnal Ekonomi Pembangunan Universitas Udayana.3(4), 164-172

Ghozali, I. (2011). Aplikasi analisis multivariate dengan program SPSS 23. Cetakan ke VIII. Universitas Diponegoro. Semarang.

Gujarati. Damodar. (2003). Economectric. Erlangga. Jakarta.

Mankiw, N. Gregory. (2007). Teori makroekonomi edisi keempat. Erlangga. Jakarta.

Muhtadi, Tien R. (2007). Program Peningkatan produksi beras 2 juta ton per Tahun. Komisi Teknis ketahanan pangan.

Noor, Henry faisal. (2007). Ekonomi manajerial. PT. Raja Grafindo Persada. Jakarta.

R Nurjanah, C Mustika. (2021).The influence of imports, foreign exchange reserves, external debt, and interest rates on the currency exchange rates against the United States Dollar in Southeast Asia Countries, Jurnal Perspektif Pembiayaan dan Pembangunan Daerah, 9 (4), 365-374 
R Rosita, H Haryadi, A Amril. (2014).Determinan Ekspor CPO Indonesia, Jurnal Perspektif Pembiayaan dan Pembangunan Daerah 1 (4), 183-183

Tambunan, Tulus. (2012). Perekonomian Indonesia: kajian teoritis dan analisis empiris. Gralia Indonesia. Jakarta.

Tan, Syamsurijal. (2016). Ilmu ekonomi Internasional (Perdagangan Internasional), cetakan pertama. Fakultas Ekonomi dan Bisnis. Universitas Jambi: Jambi. 